\title{
Effect of Different Concentrations of BAP and Putrescine on Potato Microtuberization (cv. Agria)
}

Samad KHORSANDI ${ }^{1}$, Alireza MOTALLEBİ AZAR ${ }^{1}$, Fariborz ZAARE NAHANDI ${ }^{1}$, Ali HATAMI ${ }^{1}$, Sam MOKHTARZADEH ${ }^{2 *}$

\begin{abstract}
One of the most critical stages of produced virus free potato plants is rapid and efficient in vitro microtuberization. Plant growth regulators and their concentration is important factor on potato microtuberization. This study was conducted to develop a protocol for rapid microtuber formation for

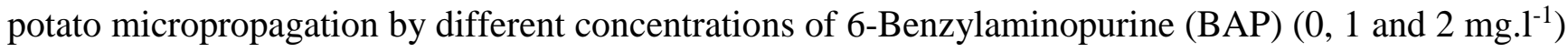
and five concentrations of Putrescine $\left(0,20,40,80\right.$ and $\left.160 \mathrm{mg} . \mathrm{l}^{-1}\right)$ with $8 \%$ sucrose and $8 \mathrm{~g} . \mathrm{l}^{-1}$ agar. Present study was conducted as a factorial experiment based on completely randomized design with three replications in tissue culture laboratory to investigate the effect of different BAP and Putrescine concentrations. Lateral buds of cv. Agria from in vitro shoots were cultured as explants. Cultures were kept in germinator with constant darkness and temperature of $17 \pm 2^{\circ} \mathrm{C}$. Variance analysis showed that none of the traits were affected by different concentrations of the Putrescine other than weight of the shoots. Also, the interaction effect of PUT $\times$ BAP on shoot weight was significant. However, the effect of different levels of BAP was significantly associated with the most trait of microtuberization. In this experiment, the best concentration of BAP for microtuberization was $1 \mathrm{mg} . \mathrm{l}^{-1}$. Also, the appropriate Putrescine level for increasing of microtuberization number and percentage was $80 \mathrm{mg} . \mathrm{l}^{-1}$ but the effect of Putrescine on microtuberization number and percentage was non-significant.
\end{abstract}

Keywords: Solanum tuberosum, in vitro, plant growth regulators, polyamine

${ }^{1}$ Samad KHORSANDI (Orcid ID: 0000-0002-1438-0433), Alireza Motallebi AZAR (Orcid ID: 0000-0002-4384-3716), Fariborz Zaare NAHANDI (Orcid ID: 0000-0003-3253-8705), Ali HATAMI (Orcid ID: 0000-0003-2989-6296), University of Tabriz, Faculty of Agriculture, Department of Horticultural Sciences, Tabriz, Iran

${ }^{2}$ Sam MOKHTARZADEH (Orcid ID: 0000-0002-3927-0855), University of Bingol, Faculty of Agriculture, Department of Field Crops, 12000 Bingol, Turkey.

*Corresponding Author: Sam MOKHTARZADEH, e-mail: sam.mokhtarzadeh@gmail.com

Geliș tarihi / Received: 26-07-2019

Kabul tarihi / Accepted: 01-03-2020 


\section{INTRODUCTION}

The potato (Solanum tuberosum L.) is an important vegetable among Solanaceae family. Vegetative propagation of potato causes potato leaf roll virus (PLRV) and potato virus Y (PVY) which result in more than $95 \%$ decrease in crop yield. On way for decreasing the viral contaminations in potato production is using plant tissue culture methods. Because of potatoes susceptibility to viral diseases, the production of virus-free plants in in vitro conditions causes the decrease of costs and increase of yields (Fatima et al., 2005). Potato propagation by in vitro culture of axillary buds is commonly used for the production of disease free plantlets, germplasm exchange, and seed tuber production. Potato tuber production through in vitro techniques was first described as an experimental tool for examining the physiological processes associated with tuberization and understanding potato pathology. Also various plant growth regulators have been used in microtuber production for increasing number and size of tuber. BAP has been shown to promote microtuber induction and development in potato (Dhital and Lim, 2012). As well as the effective factors in microtuberization include genotype, type of explant (Khuri and Moorby, 1996), photoperiod (Hussey and Stacey, 1984), temperature (Akita and Takayama, 1994), carbohydrate source (Garner and Blake, 1989). However, most of the studies on tuberization was conducted in growth regulators presence. Cytokines indirectly affect microtuberization by increasing starch synthesis enzyme activity (Sarkar et al., 2006). The increase of microtubers's function resulted in their average weight increase in MS (Murashige and Skoog, 1962) medium containing $10 \mathrm{mg} . \mathrm{l}^{-1}$ BAP sixty days after planting which was compared with non-BAP MS medium. Also, it was reported that the proper medium for planting is MS medium containing $2 \mathrm{mg} \cdot \mathrm{l}^{-1} \mathrm{BAP}$ and $6 \%$ sucrose (Hussey and Stacey, 1984). Polyamines (PAs) are a group polycation aliphatic concentrations on all prokaryotic and eukaryotic cells. Spermine (SPM), spermidine (SPD) and putrescine (PUT) are three usual types of these concentrations. It was reported that types of polyamine increase in potato stolons during tuberization which shows the role of amines in potato tuberization (Martin-Tanguy, 1997). Using polyamines (SPM, SPD, PUT) with $10^{-4} \mathrm{M}$ and $1 \mathrm{mg} . \mathrm{l}^{-1}$ IAA concentration showed that SPD acts better than other PAs for inducting potato microtuberization (Mader, 1995). Polyamines increased microtuberization on yam (Dioscorea alata L.) and it was reported that MS medium containing $10 \mu \mathrm{M}$ Putrescine $3 \%$ sucrose on 14 days led to obtain $100 \%$ of microtuberization (Ondo Ovono et al., 2009). In other hand maximum number of lateral shoots was observed in MS medium containing $50 \mathrm{mg} . \mathrm{l}^{-1}$ Nicotinic acid, $50 \mathrm{mg} . \mathrm{l}^{-1}$ Pyridoxine- $\mathrm{HCl}, 10 \mathrm{mg} . \mathrm{l}^{-1}$ Thiamine- $\mathrm{HCl}$ and $4 \mathrm{mg} . \mathrm{l}^{-1}$ BAP. Also, maximum percentage of root and callus formation was observed in combination of MS include vitamins without BAP (Kazemiani et. al., 2018).

This study was carried out to determine the best concentration of BAP and Putrescine for optimizing the rate and quantity of potato microtuberization and the interaction between them.

\section{MATERIALS AND METHODS}

This study was conducted at the Plant Tissue Culture Laboratory, Department of Horticultural Sciences, University of Tabriz. In vitro potato shoots (Solanum tuberosum cv. Agria) were sub-cultured every 3 to 4 weeks internal by placing 5 single node cuttings on each jar containing $30 \mathrm{ml}$ of semi-solid MS medium without hormones, supplemented by $20 \mathrm{~g} \cdot \mathrm{l}^{-1}$ sucrose and $8 \mathrm{~g} . \mathrm{l}^{-1}$ agar and maintained at $25 \pm 2^{\circ} \mathrm{C}$ in $16 \mathrm{~h}$ light/ $8 \mathrm{~h}$ dark photoperiod (Figure 1). Axillary buds were cut from in vitro shoot and were cultured on microtuberization medium. Microtuberization medium was including MS basal medium with various concentrations of $\operatorname{BAP}\left(0,1\right.$ and 2 mg. $\left.\mathrm{l}^{-1}\right)$ and Putrescine $(0,20,40,80$ and 160 mg..$^{-1}$ ), sucrose 80 g. $1^{-1}$ and agar 8 g..$^{-1}$. The $\mathrm{pH}$ of the culture media was adjusted to 5.8 with $\mathrm{HCl}$ or $\mathrm{NaOH}(0.5$ normal) before autoclaving. The cultures were kept in growth chamber with constant 
darkness and temperature of $17 \pm 2^{\circ} \mathrm{C}$ for a period of four months. During the first month microtuberization rate were measured and after that traits such as percentage, length, width, number and weight of microtubers and number and length of shoots growing on microtuber were measured in threemonth period. This study was carried out factorial experiment based on completely randomized design with three replications. Data obtained from this study were analyzed using SPSS software Ver.21. The means comparison carried out by Duncan's New Multiple Range Tests at $5 \%$ probably level.

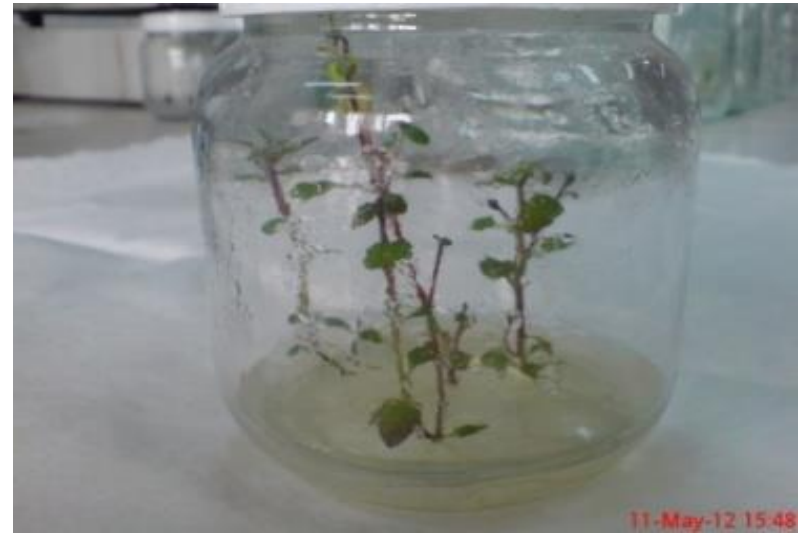

Figure 1. The shoots proliferation

\section{RESULTS AND DISCUSSION}

\section{Percentage of Microtuberization}

Data analysis of variance showed that the percentage of microtuberization in the course of data collecting within three months (second, third, and fourth month) has been significantly affected by different concentrations of BAP (Table 1), whereas there was not any significant difference between Putrescine different concentrations, and it showed that using putrescine could not be effective in improving the percentage of microtuberization. Also, PUT $\times$ BAP interaction effect was significant in the Third month only (Table 2).

Table 1. The effects of different BAP concentrations on potato microtuberization

\begin{tabular}{cccc}
\hline & Second month & Third month & Fourth month \\
\hline BAP $\left(\right.$ mg. l $\left.^{-1}\right)$ & Microtuberization (\%) & Microtuberization (\%) & Microtuberization (\%) \\
\hline $\mathbf{0}$ & $18.66 \mathrm{~b}$ & $46.66 \mathrm{~b}$ & $49.33 \mathrm{~b}$ \\
$\mathbf{1}$ & $69.66 \mathrm{a}$ & $94.33 \mathrm{a}$ & $100.00 \mathrm{a}$ \\
$\mathbf{2}$ & $62.44 \mathrm{a}$ & $83.55 \mathrm{a}$ & $98.77 \mathrm{a}$ \\
\hline
\end{tabular}

Similar letters in each column indicates no significant difference in the probability level of 5\%

The best effects of BAP concentrations on potato microtuberization observed $100 \%$ in MS medium including $1 \mathrm{mg} . \mathrm{l}^{-1}$ BAP and after four month (Table 1). Mean comparisons showed that the percentage of microtuberization in all media supplemented with BAP was increased in every 3 months, as well. However, any significant difference between concentrations of 1 and $2 \mathrm{mg} . \mathrm{l}^{-1}$ was not observed (Table 2). According to Figure 2 for increasing microtuberization percentage, the appropriate concentration of Putrescine in MS medium without BAP was in $80 \mathrm{mg} . \mathrm{l}^{-1}$. Also, the results showed that MS medium including BAP which causes change in the amount of Putrescine have a non-significant effect on microtuberization percent. In other words, the effect of a particular concentration of Putrescine is evident in the absence of BAP. The results of this study are partially parallel with studies mentioned below.

Mader (1995); observed that in the MS medium including polyamines (PUT, SPD and SPM), $100 \%$ of microtuberization was achieved after 40 days. Protacio and Flores (1992); reported that the free 
polyamines in explants increased the microtuberization in high and low percentage of sucrose concentrations. Zakaria et al. (2014); observed that the highest percentage (52.2\%) of $>300 \mathrm{mg}$ size and lowest percentage $(19.3 \%)$ of $<150 \mathrm{mg}$ size microtuber was produced in 30 days old plantlet with MS media containing $40 \mathrm{mg} \cdot \mathrm{l}^{-1} \mathrm{~K}+10 \mathrm{mg} \cdot \mathrm{l}^{-1} \mathrm{BA}+9 \%$ sucrose in the variety Diamant. Dhital and Lim (2012); reported that $1 / 2 \mathrm{MS}$ liquid medium containing $8 \%$ sucrose and $1.22 \mathrm{gl}^{-1} \mathrm{KNO}_{3}, 1.41 \mathrm{gl}^{-1}$ $\mathrm{NH}_{4} \mathrm{H}_{2} \mathrm{PO}_{4} ; 0.23 \mathrm{gl}^{-1} \mathrm{Ca}\left(\mathrm{NO}_{3}\right)_{2} 4 \mathrm{H}_{2} \mathrm{O}$; ; and $0.74 \mathrm{gl}^{-1} \mathrm{MgSO}_{4}$ produced the highest percentage (50\%) of medium to large-sized (>500 mg) microtubers. Also, Momena et al. (2014); explained that $8 \%$ Sucrose $+4 \mathrm{mg} . \mathrm{l}^{-1}$ Kinetin $+1 \mathrm{mg} . \mathrm{l}^{-1}$ BAP presented highest percentage of microtuber $(88.3 \%, 93.3 \%, 51.7 \%$ and $88.3 \%$ for Granula, Diamond, Sarpoexona and Lal Pakri1 respectively).

Table 2. The variance analysis of effects on studied traits

\begin{tabular}{|c|c|c|c|c|c|c|c|c|}
\hline SV & $\mathrm{DF}_{\mathbf{I}}$ & $\begin{array}{c}\text { Rate of } \\
\text { microtuberization }\end{array}$ & $\begin{array}{l}\text { Microtuber } \\
\text { length }\end{array}$ & $\begin{array}{c}\text { Microtuber } \\
\text { diameter }\end{array}$ & $\begin{array}{c}\text { Microtuber } \\
\text { weight }\end{array}$ & $\begin{array}{c}\text { Shoot length on } \\
\text { microtuber }\end{array}$ & $\begin{array}{c}\text { Direct shoot } \\
\text { length }\end{array}$ & $\begin{array}{l}\text { Shoot } \\
\text { weigh }\end{array}$ \\
\hline PUT & 4 & 0.94 & 1.40 & 1.08 & 0.001 & 3.63 & 9.41 & $0.02 * *$ \\
\hline BAP & 2 & $4.12 *$ & $41.11 * *$ & $27.31 * *$ & $0.09 * *$ & 15.72 & $266.15^{* *}$ & $0.33 * *$ \\
\hline $\mathrm{PUT} \times \mathrm{BAP}$ & 8 & 0.93 & 1.49 & 0.91 & 0.003 & 13.72 & 12.28 & $0.02 * *$ \\
\hline error & 30 & 0.88 & 1.17 & 0.79 & 0.003 & 7.17 & 6.63 & 0.006 \\
\hline
\end{tabular}

$*(P<0.05), * *(P<0.01)$

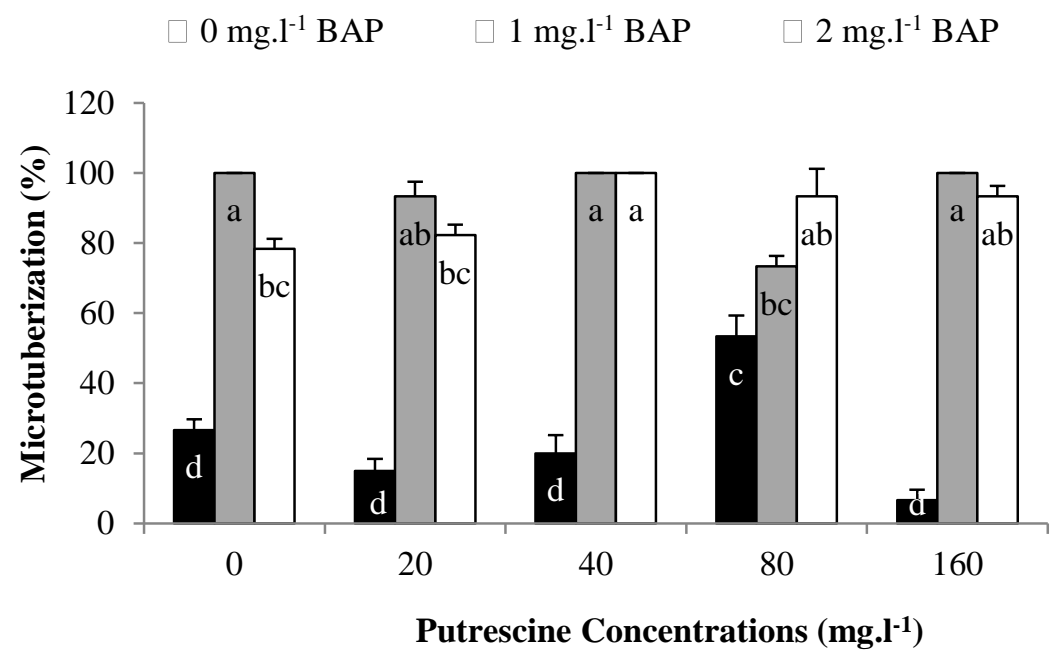

Figure 2. The average percentage of microtuberization during the third month at different concentrations of BAP and Putrescine

\section{Rate of Microtuberization}

Results showed that the effect of different concentrations of BAP on the rate of microtuberization was significant $(P<0.05)$, whereas any significant difference between different levels of Putrescine was not seen. Also, interaction between PUT and BAP was not significant (Table 2).

The best effects of BAP concentrations on rate of microtuberization observed 2.34 in MS medium including $1 \mathrm{mg} . \mathrm{l}^{-1} \mathrm{BAP}$. Mean comparison showed that there were not significant difference between two concentrations of BAP ( 1 and 2 mg. $\left.\mathrm{l}^{-1}\right)$ and maximum rate of microtuberization observed in culture mediums including BAP, whereas culture mediums without BAP had the lowest rate of microtuberization (Table 3). The results of this study are parallel with studies mentioned below.

Addition of plant growth regulators increases microtuberization rate when culture medium includes 8\% sucrose (Harmey et. al., 1966). Momena et al. (2014); reported that maximum rate of microtuber was found from MS $+8 \%$ Sucrose +4 mg. $1^{-1}$ Kinetin +1 mg..$^{-1}$ BAP $(2.3,2.7,2.0$ and 2.2/culture for Granula, Diamond, Sarpoexona and Lal Pakril respectively). Altındal and Karadoğan 
(2010) observed the highest minituber formation in 4\% maltose in Agria and Justine cultivars and stated that the effect of carbon source and concentration on tuber formation was statistically significant.

Table 3. The average traits studied at different concentrations of BAP

\begin{tabular}{|c|c|c|c|c|c|}
\hline $\begin{array}{c}\text { BAP concentrations } \\
\left(\mathrm{mg.l}^{-1}\right)\end{array}$ & $\begin{array}{c}\text { Rate of } \\
\text { microtuberization }\end{array}$ & $\begin{array}{l}\text { Microtuber } \\
\text { length }(\mathrm{mm})\end{array}$ & $\begin{array}{c}\text { Microtuber } \\
\text { diameter }(\mathrm{mm})\end{array}$ & $\begin{array}{l}\text { Microtuber } \\
\text { weight (mg) }\end{array}$ & $\begin{array}{l}\text { Direct shoot } \\
\text { length }(\mathrm{cm})\end{array}$ \\
\hline 0 & $1.40 \mathrm{~b}$ & $1.00 \mathrm{~b}$ & $0.76 b$ & $15.9 b$ & $12.33 a$ \\
\hline 1 & $2.34 \mathrm{a}$ & $3.99 \mathrm{a}$ & $3.17 \mathrm{a}$ & $168.5 \mathrm{a}$ & $4.54 b$ \\
\hline 2 & $2.26 \mathrm{a}$ & $3.72 \mathrm{a}$ & $3.03 \mathrm{a}$ & $125.9 \mathrm{a}$ & $5.65 b$ \\
\hline
\end{tabular}

Similar letters in each column indicates non-significant difference in the probability level of 5\%

\section{Dimensions of Microtuber (Microtuber Length)}

The effect of different concentrations of BAP on length of produced microtubers was significant $(P<0.01)$, whereas interaction between PUT and BAP, and the effect of different concentrations of Putrescine were not significant (Table 2). The results of mean comparison showed that the minimum length of microtuber has been created in the MS culture mediums without BAP. The best effects of BAP concentrations on microtuber length observed $3.99 \mathrm{~mm}$ in MS medium including $1 \mathrm{mg} . \mathrm{l}^{-1} \mathrm{BAP}$. Also the length of microtubers increased significantly in MS culture mediums including BAP and it was observed that the length of microtuber in culture mediums including BAP was longer than the length of microtuber in culture medium without BAP, but there was not significant difference between the concentrations of 1 and 2 mg. l $^{-1}$ of BAP (Table 3). Gopal et al. (1998); reported that the high performance of microtubers in MS culture medium including BAP was created by producing larger microtubers. Ondo Ovono et al. (2009); stated that the length and weight of microtubers with the usage of $10 \mu \mathrm{M}$ Putrescine and $3 \%$ sucrose, after 60 and 120 days were 8.8 and $10.5 \mathrm{~mm}$ respectively.

\section{Width of Microtuber (Diameter of Microtuber)}

Data analysis showed that the effect of different concentrations of BAP on width of microtubers was significant $(P<0.01)$, however, the effect of Putrescine, and PUT $\times$ BAP interaction were not significant (Table 2). The best effects of BAP concentrations on microtuber diameter observed $3.17 \mathrm{~mm}$ in MS medium including $1 \mathrm{mg} . \mathrm{l}^{-1}$ BAP. Also the results of mean comparison showed that the highest width of microtuber belonged to those obtained in MS medium including 1 and $2 \mathrm{mg}^{-1}$ BAP, respectively and there was not significant difference between them. Also, minimum width of microtuber was observed in MS mediums without BAP (Table 3). Along with these results, Gopal et al. (1997); reported that MS medium including BAP causes the increase of size and performance of Potato's microtubers. Imai et al. (2010); observed that the microtuber's diameter is an effective feature in terms of storage. Wazir et al. 2015); reported that the diameter of microtubers formed in treatment $8 \%$ sucrose differed significantly $(\mathrm{P} \leq 0.05)$ from other treatments. The microtubers of $8 \%$ sucrose were comparatively larger in size with mean diameter of $6.84 \mathrm{~mm}$. Momena et al. (2014); reported that maximum average diameter was found from MS $+8 \%$ Sucrose +4 mg..$^{-1}$ Kinetin +1 mg..$^{-1}$ BAP (4.1, 4.4, 3 and $3.9 \mathrm{~mm}$ for Granula, Diamond, Sarpoexona and Lal Pakri1 respectively) followed by MS + $6 \%$ Sucrose $+4 \mathrm{mg} . \mathrm{l}^{-1}$ Kinetin $(3.1,3.6,2.2$ and $3.4 \mathrm{~mm}$ for Granula, Diamond, Sarpoexona and Lal Pakri1 respectively) while minimum from MS + 8\% Sucrose (3.1, 3.5, 2.2 and $3.4 \mathrm{~mm}$ for Granula, Diamond, Sarpoexona and Lal Pakri1 respectively). Husain et al. (2017); observed that the plants grown in $40 \mathrm{gl}^{-1}$ sucrose level MS media were given $(2.82 \mathrm{~cm})$ micro-tuber diameter. It means that $40 \mathrm{gl}^{-1}$ sucrose gives good food to plant which resulted in more micro-tuber diameter. Altındal and Karadoğan (2010); reported that optimal tuber diameter was obtained on $4 \%$ maltose in Justine and $6 \%$ sucrose in Agria. 


\section{Number of Microtubers}

Analysis of variance (ANOVA) showed that the effect of different concentrations of BAP on the number of produced microtubers was significant in each of the three months $(P<0.05)$, however, the effect of different concentrations of Putrescine and PUT $\times$ BAP interaction was not significant (Table 2). The number of microtubers depended on different concentrations of BAP. Therefore, in every three months, the highest number of produced microtuber was observed 5.15 in mediums containing $1 \mathrm{mg} .1^{-1}$ BAP, although non-significant difference was observed between both concentrations (1 and 2 mg. $1^{-1}$ ), but, the minimum number of microtuber was obtained in the culture mediums without BAP. Also, it was observed that in culture mediums including 20 and $40 \mathrm{mg} \cdot \mathrm{l}^{-1}$ of Putrescine and without BAP, the average number of microtuber production is very low and it was almost equal with control culture medium. In this study, use of $80 \mathrm{mg} .1^{-1}$ Putrescine increased the number of microtuber. It was also observed that in concentrations higher than $80 \mathrm{mg} .1^{-1}$ of Putrescine, microtuber numbers decrease (Figure 3).

Gopal et al. (1998); and Pelacho et al. (1991); reported that MS medium including 4 and 5 mg. $\mathrm{l}^{-1}$ of BAP increased the number of produced microtubers in potato plants. A relatively higher number of microtubers observed in treatments with sucrose concentration $3 \%$ and $8 \%$ while in the control treatment (0\%) no microtubers were formed (Wazir et al., 2015). Maximum number of microtubers (12.8) was obtained in MS medium containing $5 \mathrm{mg} . \mathrm{l}^{-1} \mathrm{BAP}, 50 \mathrm{mg} . \mathrm{l}^{-1}$ coumarin and $8 \%$ sucrose that followed by MS medium including $5 \mathrm{mg} . \mathrm{l}^{-1} \mathrm{BAP}, 500 \mathrm{mg} . \mathrm{l}^{-1} \mathrm{CCC}$ and $8 \%$ sucrose that contained growth retardant (Zakaria et al., 2014). Gami et al. (2013); explained that for microtuber production, high level of sucrose (8\%) gave promising results than low level of sucrose (3\%). Also Dhital and Lim (2012); showed that $1 / 2$ MS liquid medium containing $8 \%$ sucrose and $\mathrm{KNO}_{3}, 1.22 \mathrm{gl}^{-1} ; \mathrm{NH}_{4} \mathrm{H}_{2} \mathrm{PO}_{4}, 1.41 \mathrm{gl}^{-1}$; $\mathrm{Ca}\left(\mathrm{NO}_{3}\right)_{2} 4 \mathrm{H}_{2} \mathrm{O}, 0.23 \mathrm{gl}^{-1}$; and $\mathrm{MgSO}_{4}, 0.74 \mathrm{gl}^{-1}$ produced the highest number of microtubers. Momena et al. (2014); reported that different hormonal combinations showed variation in microtuber formation. Treatment $8 \%$ Sucrose $+4.00 \mathrm{mg} . \mathrm{l}^{-1}$ Kinetin $+1.00 \mathrm{mg} . \mathrm{l}^{-1}$ BAP showed maximum number of microtuber (53.0, 56.0, 31.0 and 53.0 for Granula, Diamond, Sarpoexona and Lal Pakri1 respectively).

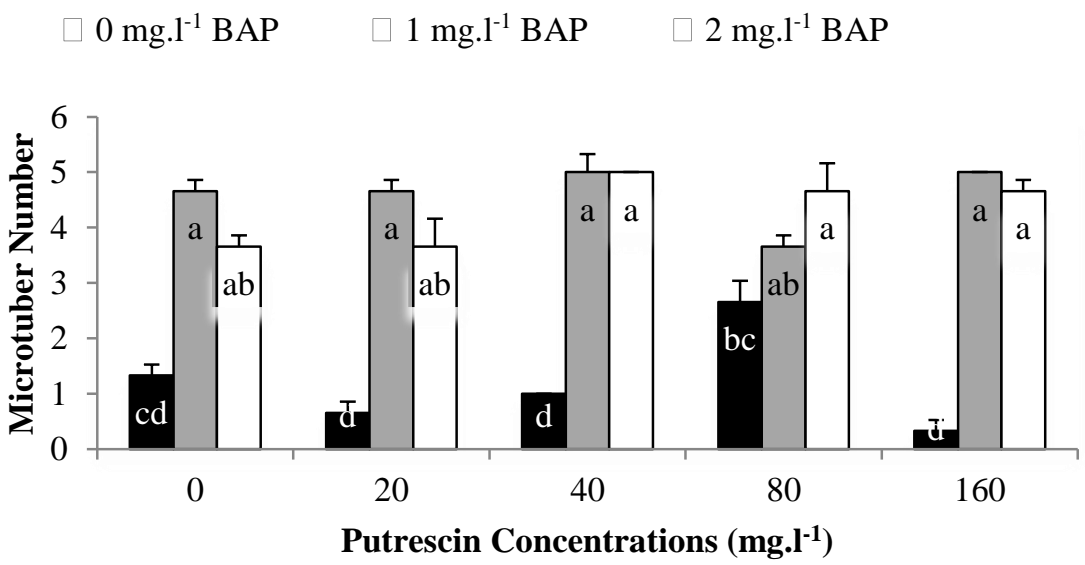

Figure 3. The average number of microtuber produced during the third month

\section{Weight of Microtubers}

Data analysis showed that the weight of microtubers was affected by BAP levels, any significant differences was not seen between the different concentrations of Putrescine. Also, PUT $\times$ BAP interaction was not significant (Table 2). Mean comparison showed that the maximum weight of microtubers belonged to MS mediums including BAP and average weight of microtubers which was $168.5 \mathrm{mg}$ in MS 
medium including $1 \mathrm{mg} . \mathrm{l}^{-1}$ of BAP that was not significantly different from MS medium including 2 mg. $1^{-1}$ of BAP. However, this amount reduced to 15.9 mg. $\mathrm{l}^{-1}$ in MS mediums without BAP (Table 3). The results of this study are partially parallel with studies mentioned below.

It was reported that the increase of microtubers performance by using $10 \mathrm{mg} \cdot \mathrm{l}^{-1}$ of BAP 60 days after the beginning of cultivation increased the average weight of microtubers in comparison with the MS mediums without BAP (Hussey and Stacey, 1984). Hoque (2010); reported that MS medium including $4 \mathrm{mg} . \mathrm{l}^{-1}$ of kinetin with $6 \%$ sucrose increased the average weight of microtubers up to $397 \mathrm{mg}$. Zakaria et al. (2014); showed that the higher average weight of microtuber was obtained in the 30 days old plantlet with MS media containing $40 \mathrm{mg} . \mathrm{l}^{-1} \mathrm{~K}+10 \mathrm{mg} \cdot \mathrm{l}^{-1} \mathrm{BAP}+9 \%$ sucrose, MS media including $10 \mathrm{mg} \cdot \mathrm{l}^{-1} \mathrm{BA}$ and $8 \%$ sucrose and MS media with $5.0 \mathrm{mg} \cdot \mathrm{l}^{-1} \mathrm{BAP}$ and $6 \%$ sucrose which contained BA in absence of growth retardant. Momena et al. (2014); reported that maximum average weight was found from MS + 8\% Sucrose + 4.00 mg..$^{-1}$ Kinetin + 1.00 mg. $1^{-1}$ BAP $(93.47,97.61,73.26$ and $87.69 \mathrm{mg}$ for Granula, Diamond, Sarpoexona and Lal Pakri1 respectively). Wazir et al. (2015); observed that the highest mean weight of microtubers was observed in treatment $8 \%(97.0 \mathrm{mg})$ followed by $3 \%(70.00$ $\mathrm{mg}), 6 \%(57.50 \mathrm{mg})$ and $11 \%(55.50 \mathrm{mg})$ sucrose concentrations. Husain et al. (2017); observed that heavier micro-tuber produced by the plants grown in 40 g..$^{-1}$ sucrose level MS media were given (1.92 g) micro-tuber weight. Altındal and Karadoğan (2010); reported that highest total tuber weight was found $4 \%$ maltose in Justine and $10 \%$ sucrose in Justine.

\section{Weight of Shoots}

The effect of different concentration of putrescine and BAP on the weight of shoots was significant $(P<0.01)$. Also, PUT $\times$ BAP interaction was significant (Table 2$)$. Results showed that the highest weight of shoots achieved in MS medium including 40 and $80 \mathrm{mg} \cdot \mathrm{l}^{-1}$ of Putrescine. However, the weight of shoots in MS medium including 1.00 and $2.00 \mathrm{mg} . \mathrm{l}^{-1}$ of BAP was decreased. The highest weight of shoots observed $523 \mathrm{mg}$ in MS medium including $40 \mathrm{mg} . \mathrm{l}^{-1}$ Putrescine (Figure 4). It has been reported that polyamines increase regeneration and cell division of organs in plant tissue culture (Kakkar et al., 2000). Also, polyamines such as putrescine and spermidine increase the regeneration of cabbage plant and sugar beet in in vitro conditions, which results in the increase of weight and performance of shoots, compared to control treatment (Saiprasad and Raghuveer, 2004).
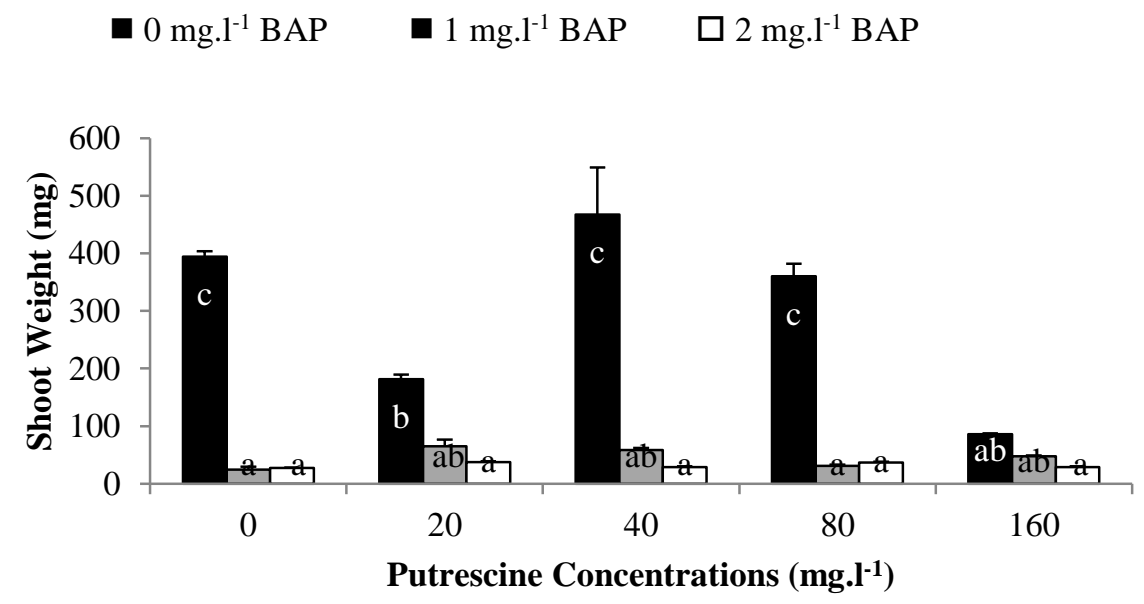

Figure 4. Average weight of shoots at different concentrations of BAP and Putrescine 


\section{Length of Grown Shoots from Nodes (Direct Shoots)}

Variance of analysis showed that the effect of different concentration of BAP on direct shoots length was significant $(P<0.01)$, whereas, the effect of different concentrations of putrescine and PUT $\times$ BAP interaction was not significant (Table 2). Results showed that growth of direct shoots was increased in MS medium without BAP. Also, length of direct shoots in MS medium without BAP was higher than other mediums, while, the average length of direct shoots in MS medium containing 1 and $2 \mathrm{mg} . \mathrm{l}^{-1}$ of BAP was lower compared to MS mediums without BAP, and there was not significant difference between BAP concentrations. Also the best direct shoot $(12.33 \mathrm{~cm})$ achieved in MS medium without BAP (Table 3). Hoque (2010); reported that shoots length increased in MS medium including 2 mg. $1^{-1}$ of kinetin, but the number of shoots decreased. Also, shoots length decreased in MS medium including $4 \mathrm{mg} . \mathrm{l}^{-1}$ of kinetin, but the number of shoots increased. Zhang et al. (2005); observed that the largest shoots length was obtained on MS mediums containing 5 and $10 \mathrm{mg} . \mathrm{l}^{-1}$ of IAA with or without $5 \mathrm{mg} . \mathrm{l}^{-1}$ of $\mathrm{GA}_{3}$. Also, they explained that $5 \mathrm{mg} . \mathrm{l}^{-1}$ of BAP has a negative effect on shoot growth. Wazir et al. (2015); reported that the highest mean shoot length $(8.28 \mathrm{~cm})$ was observed in treatment with $3 \%$ sucrose level followed by $6 \%$ sucrose in which the mean shoot length was $6.40 \mathrm{~cm}$.

\section{CONCLUSION}

The highly heterozygous character of potato in generative production cause problems. Therefore, vegetative propagation for maintaining cultivars of potato's genetic integrity is suggested. Microtuberization of potato is intricate process. For coping with this problem, microtuberization can be obtained by using the biotechnological techniques. In vitro culture techniques create $100 \%$ viruse-free microtubers. In this study it has been tried to establish a protocol for potato microtuberization in in vitro condition by different concentrations of BAP and Putrescine. The results of this study clearly showed that the best concentration of BAP for microtuberization was $1.00 \mathrm{mg} . \mathrm{l}^{-1}$. Also, it was stated that the appropriate Putrescine level for increasing microtuberization number and percentage was $80 \mathrm{mg} . \mathrm{l}^{-1}$. The results of this experiment will shed light to further studies of potato microtuberization. Also, it is thought that this protocol will direct the commercial microtubing studies.

\section{REFERENCES}

Akita M, Takayama S, 1994. Induction and development of potato tubers in a jar fermenter. Plant Cell, Tissue and Organ Culture, 36: 177-182.

Altindal D, Karadoğan T, 2010. The Effect of Carbon Sources on In Vitro Microtuberization of Potato (Solanum tuberosum L.). Turkish Journal of Field Crops, 15(1): 7-11.

Dhital SP, Lim HT, 2012. Microtuberization of Potato (Solanum tuberosum L.) as Influenced by Supplementary Nutrients, Plant Growth Regulators, and In Vitro Culture Conditions, Potato Research, 55 (2): 97-108.

Fatima B, Usman M, Ahmad I, Khan IA, 2005. Effect of explant and sucrose on microtuber induction in potato cultivars. International Journal of Agriculture and Biology, 7: 63-66.

Gami RA, Parmar SK, Patel PT, Tank CJ, Chauhan RM, Bhadauria HS and Solanki SD, 2013. Microtuberization, minitubers formation and in vitro shoot regeneration from bud sprout of potato (Solanum tuberosum L.) cultivar K. badshah, African Journal of Biotechnology, 12(38): 5640-5647.

Garner N, Blake J, 1989. The induction and development of potato microtubers in vitro on media free of growth regulating substances. Annals of Botany, 63:663-674.

Gopal J, Minocha JL, Sidhu JS, 1997. Comparative performance of potato crops raised from microtubers induced in dark versus microtubers induced in light. Potato Research, 40: 407-412.

Gopal J, Minocha JL, Dhaliwal HS, 1998. Microtuberization in potato (Solanum tuberosum L.). Plant Cell Reports, 16: 794-798. 
Harmey MA, Crowley MP, Clinch PEM, 1966. The effect of growth regulators on tuberization of cultured stem pieces of Solanum tuberosum. Eur. Potato J, 9: 146-151.

Hoque ME, 2010. In Vitro Regeneration Potentiality of Potato under Different Hormonal Combination. World Journal of Agricultural Sciences (WJAS), 6 (6): 660-663.

Husain S, Hussain Shah SA, Asghar S, Hussain N, Ali N, Hussain I, Rafiq S, Shah S, Imtiaz M, Ali M, Jala F, Zia-ullah and Rashid M, 2017. Micro-Tuberization of Four Potato (Solanum tuberosum L.) Cultivars Through Tissue Culture. Journal of Botanical Sciences, 6(3): 35-40.

Hussey G, Stacey NJ, 1984. Factors affecting the formation of in vitro tubers of potato (Solanum tuberosum L.). Annals of Botany, 53: 565-578.

Imai AA, Qhrmanzadeh R, Azimi J, Janpoor J, 2010. The effect of various of 6-benzylaminopurine (BAP) and sucrose on in vitro potato (Solanum tuberosum L.) microtuber induction. American-Eurasian Journal of Agricultural and Environmental Sciences, 8(4): 457-459.

Kakkar RK, Nagar PK, Ahuja PS, Rai VK, 2000. Polyamines and plant morphogenesis. Biologia Plantarum, 43: 1-11.

Kazemiani S, Motallebi-Azar AR, Panahandeh J, Mokhtarzadeh S, Ozdemir FA, 2018. Shoot proliferation from potato (Solanum tuberosum cv. Agria) under different concentration of MS include vitamins and BAP medium. Progress in Nutrition, 2018; , 20 (1) 160-166.

Khuri S, Moorby J, 1996. Nodal segments or microtubers as explants for in vitro microtuber production of potato. Plant Cell, Tissue and Organ Culture, 45: 215-222.

Mader JC, 1995. Polyamines in Solanum tuberosum in vitro: Free and conjugated polyamines in hormone-induced tuberization. Journal of Plant Physiology, 146: 115-120.

Martin-Tanguy J, 1997. Conjugated polyamines and reproductive development: biochemical, molecular and physiological approaches. Physiologia Plantarum, 100: 675-688.

Momena K, Adeeba R, Mehraj H, Jamal Uddin AFM, Saiful Islam and Rahman L, 2014. In Vitro Microtuberization of Potato (Solanum Tuberosum L.) Cultivar through Sucrose and Growth Regulator. Journal of Bioscience and Agriculture Research, 02 (02): 76-82.

Murashige T, Skoog F, 1962. A revised medium for rapid growth and bioassay with tobacco tissue cultures. Physiologia Plantarum, 15: 473-497.

Ondo Ovono P, Kevers C, Dommes J, 2009. Tuber formation and development of Dioscorea cayenensis and D. rotundata complex. Effect of Polyamines. In Vitro Cellular \& Developmental Biology Plant, 46: 81-88.

Pelacho AM, Mingo-Castel AM, 1991. Effects of photoperiod on kinetin-induced tuberization of isolated potato stolons cultured in vitro. American Journal of Potato Research, 86:533-541.

Protacio CM, Flores HE, 1992. The role of polyamines in potato tuber formation. In Vitro Cellular \& Developmental Biology, 28: 81- 86.

Saiprasad GVS, Raghuveer P, 2004. Effect of various polyamines on production of protocorm-like bodies in orchid Dendrobium 'Sonia'. Scientia Horticulturae, 100: 161-168.

Sarkar D, Pandey SK, Sharma S, 2006. Cytokinins antagoniz the jasmonates action on the regulation of potato (Solanum tuberosum L.) tuber formation in vitro. Plant Cell, Tissue and Organ Culture, 87:285-295.

Wazir A, Gul Z, Hussain M, Ullah Khan Z, Saleem M, Khurshid I, 2015. Effect of sucrose on inducing in vitro microtuberization in potato without using any growth hormone. International Journal of Agronomy and Agricultural Research, 7(1): 118-124.

Zakaria M, Hossain MM, Khaleque Mian MA, Hossain T, 2014. Performance of different protocols on in vitro tuberization in Potato (Solanum tuberosum). Bangladesh Journal of Agricultural Research, 39(1): 59-66.

Zhang ZJ, Zhou WJ, Li HZ, 2005. The role of GA, IAA and BAP in the regulation of in vitro shoot growth and microtuberization in potato (Solanum tuberosum L.). Acta Physiologiae Plantarum, 27: 363- 369. 